\title{
GAMBARAN REAKSI RADANG LUKA ANTEMORTEM YANG DIPERIKSA 1 JAM POSTMORTEM PADA HEWAN COBA
}

\author{
${ }^{1}$ Fariz R Kawulusan \\ ${ }^{2}$ Sonny J. R. Kalangi \\ ${ }^{2}$ Martha M. Kaseke \\ ${ }^{1}$ Kandidat Skripsi Fakultas Kedokteran Universitas Sam Ratulangi Manado \\ ${ }^{2}$ Bagian Anatomi - Histologi Fakultas Kedokteran Universitas Sam Ratulangi Manado \\ Email: Fariz_Kawulusan@yahoo.com
}

\begin{abstract}
The skin is a protective layer of bone and is the largest organ of the function as protection against a wide variety of disorders, the effect of both physical and chemical influences. So that the skin is very susceptible to trauma and injury. Determination or more accurately estimate the age of the wound, although difficult in doing sometimes need to be made by doctors and conclusions contained in the visum et repertum, for example in cases of reconstruction are encountering difficulties in its implementation which means hamper the investigation process. A medical personnel need to master the knowledge of the injury before death (antemortem) and after death ( Postmortem ), in this case to determine the time of death. The goal is to facilitate post mortem et repertum make good and true. This study aims to determine the description of the antemortem wound inflammation in check 1 hour postmortem. This was a descriptive experimental study. A domestic pig weighing $20 \mathrm{~kg}$ was used as sample. The pig was physically healthy, smooth skin, no injuries, and no skin defects. The study consisted of 3 stages. First, isolated and fed the test animal; second, making incisions; third, network retrieval and presentation of results. Based on the results, the dead animal tissues were still able to deliver an inflammatory reaction until 1 hour post mortem. This shows that the determination of the intravital signs in forensic medicine should also consider the possibility of injuries occured immediately after death.
\end{abstract}

Keywords: Injury, Inflammation Reaction, antemortem injury process, postmortem wounds.

\begin{abstract}
Abstrak: Kulit merupakan lapisan pelindung tulang dan merupakan organ terbesar dengan fungsi sebagai proteksi terhadap berbagai macam gangguan, baik pengaruh fisik maupun pengaruh kimia. Sehingga kulit sangat rentan terhadap trauma dan terjadinya luka. Penentuan atau lebih tepatnya perkiraan umur luka, walaupun sukar di lakukan kadang-kadang perlu dibuat oleh dokter dan dimuat didalam kesimpulan visum et repertum, misalnya dalam kasus-kasus rekonstruksi yang menemui kesulitan didalam pelaksanaanya yang berarti menghambat proses penyelidikan. Seorang tenaga medis perlu menguasai pengetahuan tentang terjadinya luka sebelum meninggal (Antemortem) dan setelah meninggal (Postmortem), dalam hal ini untuk menentukan waktu kematian. Tujuannya untuk mempermudah membuat visum et repertum yang baik dan benar. Penelitian ini bertujuan untuk mengetahui Gambaran reaksi radang luka antemortem yang di periksa 1 jam postmortem. Penelitian ini bersifat deskriptif eksperimental. Sampel penelitian mengunakan satu ekor babi domestik dengan berat $20 \mathrm{~kg}$, secara fisik babi sehat, kulit mulus, tidak luka, dan tidak cacat. Penelitian dimulai dengan melakukan 3 tahap. Pertama, isolasi dan pemeliharaan hewan uji, kedua pembuatan luka insisi, ketiga pengambilan jaringan dan penyajian hasil. Berdasarkan penelitian yang telah dilakukan, pada jaringan hewan coba yang telah mati, ternyata masih dapat memberikan reaksi radang sampai 1 jam setelah pemulihan. Ini menunjukan bahwa penentuan tanda intravital kedokteran forensik harus mempertimbangkan juga kemungkinan luka yang terjadi segera setelah kematian.
\end{abstract}

Kata kunci: Luka, Reaksi Radang, Proses Luka Antemortem, Luka Postmortem. 
Kulit merupakan lapisan pelindung tulang dan merupakan organ terbesar dengan fungsi sebagai proteksi terhadap berbagai macam gangguan, baik pengaruh fisik maupun pengaruh kimia. Sehingga kulit sangat rentan terhadap trauma dan terjadinya luka. ${ }^{1}$

Luka sendiri didefinisikan sebagai diskontinuitas dari suatu jaringan atau suatu keadaan hilang atau rusaknya sebagian dari jaringan tubuh. Luka merupakan suatu proses kompleks tetapi sistemik, ada juga yang mengatakan bahwa luka merupakan suatu proses tubuh untuk memperbaiki kerusakan yang terjadi agar kembali ke bentuk anatomis dan bentuk semula, luka sendiri dapat disebabkan oleh karena teriris oleh instrumen yang tajam misalnya akibat pembedahan atau percobaan pembunuhan. ${ }^{2-4}$

Penentuan atau lebih tepatnya perkiraan umur luka, walaupun sukar dilakukan kadang-kadang perlu dibuat oleh dokter dan dimuat dalam kesimpulan visum et repertum, misalnya dalam kasus-kasus dimana rekonstruksi menemui kesulitan dalam pelaksanaanya yang berarti menghambat proses penyelidikan. ${ }^{5}$ Sehingga seorang tenaga medis perlu menguasai pengetahuan tentang terjadinya luka sebelum meninggal (Antemortem) dan setelah meninggal (Postmortem), dalam hal ini untuk menentukan waktu kematian. Tujuannya untuk mempermudah membuat visum et repertum yang baik dan benar. ${ }^{6-8}$

Berdasarkan latar belakang di atas, penulis tertarik untuk melakukan penelitian terhadap gambaran histologi luka sebelum mati (Antemortem) yang di periksa 1 jam setelah mati (postmortem). Penelitian akan menggunakan media hewan babi yang merupakan mamalia yang memiliki struktur anatomi dan fisiologi tidak jauh berbeda dengan manusia ${ }^{9}$

\section{METODE PENELITIAN}

Penelitian ini merupakan penelitian deskriptif-eksperimental, yang dilakukan di Peternakan Kalasey, Laboratorium Histologi dan Pusat Diagnostik Patologi Anatomi mulai akhir bulan november 2013 sampai bulan Februari 2014. Subjek penelitian yaitu satu ekor babi, dengan kriteria: Berat babi $20 \mathrm{~kg}$, Secara fisik: Aktif, Sehat, tidak ada luka.

\section{Prosedur penelitian}

\section{Pemeliharaan Babi}

Babi dipelihara dalam kandang dan selama pemeliharaan diberi makan konsentrat/konga makanan babi

\section{Pembuatan luka insisi}

Pembuatan luka dilakukan pada 1 ekor babi. Rambut dipunggung kanan dicukur secara hati-hati. Dengan cara dicukur rambutnya kemudian dicuci dengan alkohol $70 \%$ dan di lakukan anastesi dengan lidokain HCL 2\% yang diencerkan dengan aquades dengan perbandingan 1:3. Kemudian dibuat Luka insisi punggung kanan atas dan punggung kanan bawah, luka insisi vertikal, panjang $3 \mathrm{~cm}$, kedalaman $1 \mathrm{~cm}$. dibuat perlukaan dari 48 jam. 24 jam. 180 menit. 150 menit, 120 menit, 90 menit, 60 menit. 30 menit. 0 menit. luka tidak dijahit.

\section{Perlakuan terhadap hewan uji}

Luka pada punggung kanan atas yang telah diinsisi ini diamati pada 48 jam, 24 jam, 180 menit, 150 menit, 120 menit, 90 menit, 60 menit, 30 menit, 0 menit dan selalu ditandai dengan spidol. Kemudian, pada 0 menit, hewan coba di bunuh, setelah hewan coba tidak bernafas. Hewan itu dinyatakan mati. Kemudian perlukaan yang sebelumnya telah dibuat dari 48 jam, 24 jam, 180, 150, 120, 90, 60, 30, 0 menit. kemudian setiap sampel difiksasi dengan formalin $10 \%$ dan disiap-kan untuk pembuatan preparat histologik potongan memanjang mengikuti garis luka. Selanjutnya preparat dibaca dan dikonfirmasi oleh pembimbing,dokter ahli patologi anatomi dan histologi dengan menggunakan mikroskop cahaya pembesaran 40x. Kemudian dimulai dari 0 menit waktu mati. Luka di punggung kanan bawah dibiarkan ditunggu sekitar 60 menit, setelah 60 menit jaringan perlukaan di ambil, mulai dari waktu 30,60 , 90, 120, 150, 180 menit, 24 jam, 48 jam. 
Kemudian setiap sampel difiksasi dengan formalin $10 \%$ dan disiapkan untuk pembuatan preparat histologik potongan memanjang mengikuti garis luka. Selanjutnya preparat dibaca dan dikonfirmasi oleh pembimbing, dokter ahli patologi anatomi dan histologi dengan menggunakan mikroskop cahaya pembesaran 40x.

\section{Pembuatan Preparat}

Pembuatan preparat di lakukan di lab Patologi anatomi, pada penelitian ini, pembuatan preparat histologik dilakukan dengan cara, pemotongan memanjang mengikuti garis luka. Selanjutnya preparat dibaca dan dikonfirmasi oleh pembimbing, dokter ahli patologi anatomi dan histologi. (Gambar 1)

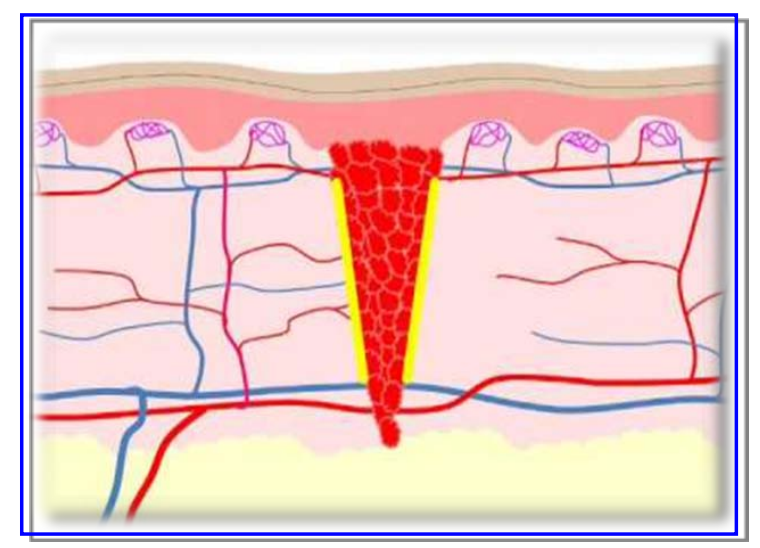

Gambar 1. Potongan Preparat

\section{HASIL PENELITIAN}

1. Gambaran luka 0 menit sesudah dibuat luka

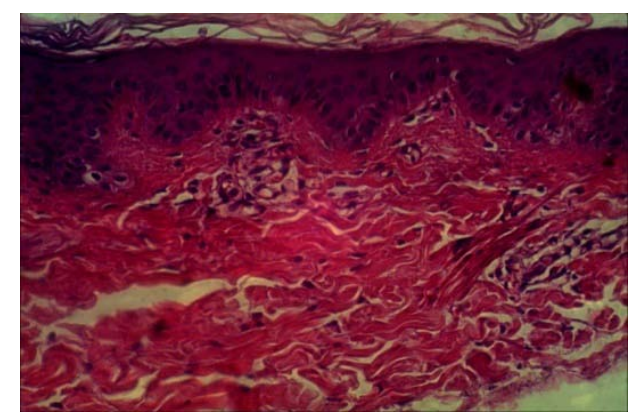

Gambar 1. Mikroskopik potongan kulit babi pada daerah luka yang dibuat 0 menit sesudah dibuat luka. terlihat adanya sel-sel inflamasi dalam jumlah yang sedikit (Pembesaran 40x).
2. Gambaran luka yang dibuat 60 menit sesudah dibuat luka

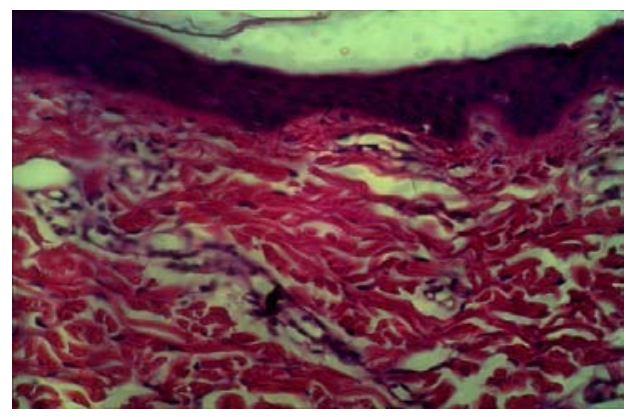

Gambar 2. Mikroskopik potongan kulit babi pada daerah luka yang dibuat 60 menit sedudah dibuat luka. terlihat adanya peningkatan sel- sel inflamasi dalam jumlah yang sedang (Pembesaran 40x)

3. Gambaran luka yang dibuat 48 jam sesudah dibuat luka

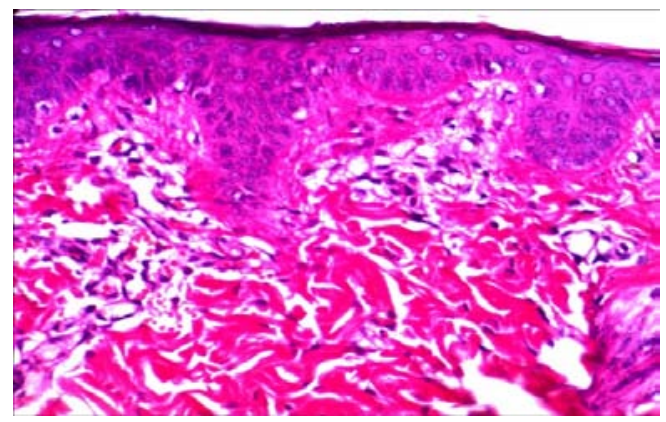

Gambar 3. Mikroskopik potongan kulit babi pada daerah luka yang dibuat 48 jam sesudah dibuat luka. terlihat peningkatan sel-sel inflamasi dalam jumlah yang banyak (40x)

4. Gambar luka yang dibuat 60 menit antemortem kemudian diambil 1 jam postmortem

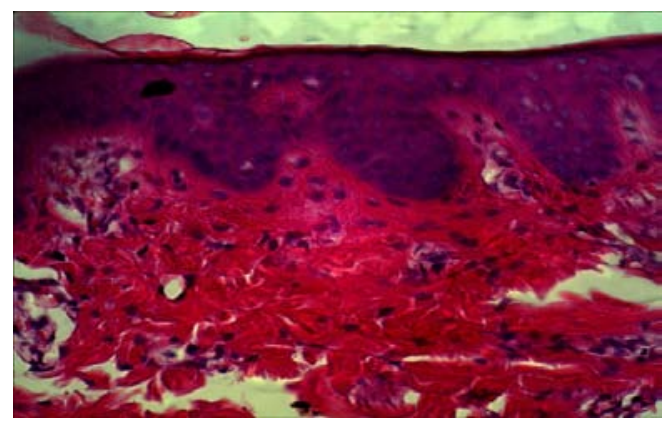

Gambar 4. Mikroskopik potongan kulit babi pada daerah luka yang dibuat 60 menit antemortem kemudian diambil 1 jam postmortem. terlihat peningkatan sel-sel inflamasi dalam jumlah yang sedang (Pembesaran 40x) 
5. Gambar luka yang dibuat 48 jam antemortem kemudian diambil 1 jam postmortem

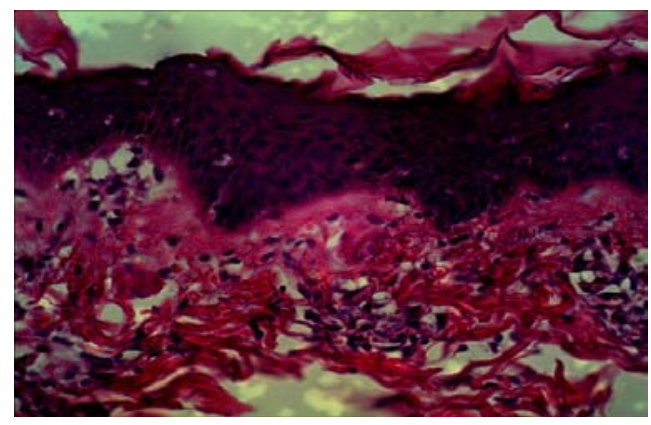

Gambar 5. Mikroskopik potongan kulit babi pada daerah luka yang dibuat 48 jam antemortem kemudian diambil 1 jam postmortem. terlihat peningkatan sel-sel inflamasi dalam jumlah yang banyak (Pembesaran 40x)

\section{BAHASAN}

Penelitian ini dilakukan untuk melihat gambaran histologi reaksi radang luka antemortem yang diperiksa 1 jam postmortem pada hewan coba.

Reaksi radang merupakan respon jaringan kompleks terhadap cedera atau antigen, yang terdiri dari (1) peningkatan vasodilatasi dan permeabilitas vaskular dengan ektravasasi dari cairan dan (2) emigrasi dari leukosit yang berasal dari sirkulasi menuju jaringan dimana leukosit akan tersebar dan diaktifkan untuk meregulasi penyembuhan dan perbaikan. Terlepas dari agen yang merangsang, mekanisme dari pertahanan tubuh tetap konsisten dan bermanifestasi klinis sebagai nyeri, panas, kemerahan, dan bengkak. Respon inflamasi berfungsi untuk menurunkan, menyingkirkan, atau menahan patogen atau jaringan cedera disaat leukosit bergerak untuk melindungi tubuh dari cedera. Suatu jaringan dari interaksi sel ke sel didorong oleh peptida dan lipid molekoler memberi isyarat untuk mendorong dan mempertahankan reaksi inflamasi dengan bertindak pada sel endotel, memicu pengerahan leukosit, dan meningkatkan aktivitas biokimia, "endocytic", dan sintesis dari fagositosis leukosit. Selanjutnya, ketika stimulus inflamasi bersifat antigenik, sel $\mathrm{T}$ dan produk ekskresinya menambah tingkatan dari amplifikasi dan kompleksitas pertahanan tubuh. Definisi lanjutan dari interaksi mediator ke sel dan sel ke sel akan mengkontribusikan wawasan penting dalam kejadian fisiologi dan patologi yang berhubungan dengan inflamasi dan perbaikan ${ }^{10}$

Pada fase radang berlangsung sejak terjadinya luka sampai kira-kira hari kelima. pembuluh darah yang terputus pada luka akan menyebabkan perdarahan dan tubuh berusaha menghentikannya dengan vasokonstriksi, pengerutan ujung pembuluh darah yang putus, dan reaksi hemostatis. Hemostatis terjadi karena trombosit yang keluar dari pembuluh darah saling melekat, dan bersama jala fibrin yang terbentuk, membekukan darah yang keluar dari pembuluh darah yang keluar dari pembuluh darah. Trombosit yang berlekatan akan berdegranulasi, melepas kemoaktraktan yang menarik sel radang, mengaktifkan fibroblast lokal dan sel endotel serta vasokonstriktor. Sementara itu, terjadi reaksi inflamasi. ${ }^{11}$

Memperkirakan saat kematian yang mendekati ketepatan sangatlah penting. Untuk dapat memperkirakan saat kematian perlu di ketahui perubahan-perubahan yang terjadi pada tubuh yang sudah meninggal dunia, dan juga faktor-faktor apa saja yang berperan di dalam terjadinya perubahanperubahan tersebut. Faktor-faktor yang mempengaruhi perubahan pada mayat yaitu terjadinya penurunan suhu, terbentuknya lebam mayat, terbentuknya kaku mayat, terjadinya pembusukan, terjadinya adipocere dan mumifikasi serta terjadinya perubahanperubahan biokimiawi. ${ }^{12}$

Autolisis merupakan perlunakan dan pencairan jaringan yang terjadi dalam keadaan steril. Autolisis timbul akibat kerja digestif oleh enzim yang dilepaskan sel pasca-mati dan hanya dapat dicegah dengan pembekuan jaringan. ${ }^{13}$

Pada penelitian ini reaksi inflamasi yang terjadi pada jaringan luka (postmortem). Pada batas waktu yang dilakukan pada penelitian ini. Memiliki gambaran histologik yang sukar dibedakan dengan 
reaksi radang yang di ambil pada jarigan luka (antemortem).

Sehingga sebagai aplikasi dari dunia forensik,untuk penentuan tanda intravital harus mempertimbangkan juga kemungkinan luka yang terjadi segera setelah kematian.

\section{SIMPULAN}

Berdasarkan hasil penelitian dapat disimpulkan bahwa Pada jaringan hewan coba yang telah mati, ternyata masih dapat memberikan reaksi radang. sampai 1 jam setelah pemulihan. Ini menunjukan bahwa penentuan tanda intravital kedokteran forensik harus mempertimbangkan juga kemungkinan luka yang terjadi segera setelah kematian.

\section{SARAN}

Parameter waktu pada manusia masih sulit di tentukan mengingat sulitnya subjek penelitian. Oleh karena itu perlu dilakukan penelitian lebih lanjut dengan waktu yang lebih panjang untuk melihat gambaran histologik proses penyembuhan luka lanjutan dalam keadaan postmortem. Kemudian diperlukan variasi potongan luka agar gambaran luka lebih baik, sehingga dapat terlihat proses yang lebih akurat.

\section{UCAPAN TERIMA KASIH}

Terima kasih kepada DR.dr. Sunny Wangko, Msi, PA(K) Selaku Dosen penguji, DR.dr Taufiq pasiak, M.pd (I), M.Kes Selaku Dosen Penguji I, dr.G.N. Tanudjaja, MS, PA(K) Selaku Dosen Penguji II, Dan DR.dr.Erwin Kristanto, SH, SpF Selaku Dosen Penguji pakar dan semua pihak baik secara langsung maupun tidak langsung yang sudah memberikan ide, saran, pendapat dan bantuan dalam penelitian maupun penyelesaian artikel ini.

\section{DAFTAR PUSTAKA}

1. Wasitaatmadja SM. Anatomi kulit. Ilmu penyakit kulit dan kelamin (Edisi ke-6). Jakarta: FKUI, 2011; h.3-5

2. Histology of the blood vessels, slide share [serial on the internet]. 2013 [cited 2013 okt 5]. Available from: http://www.course web.uottawa.ca/medicinehistology/english/c ardiovascular/histologybloodvessels.htm.

3. Histologi Pembuluh darah, slide share. [cited 2013 okt 5]. Avaible from: http://www.scribd.com/doc/69986815/HIST OLOGI-PEMBULUH-DARAH

4. Susanti R. Traumatologi. Slide share. [cited 2013 okt 5]. Available from: http://fkunand2010.files.wordpress.com/201 3/04/traumatologirk.ppt.

5. Idries AM, Tjiptomartono AL. Penentuan umur luka. Penerapan ilmu kedokteran forensik dalam proses penyelidikan Jakarta: Sagung Seto, 2008; h.137.

6. Fitriah WW, Mashuri M, Irhamah. Faktorfaktor yang mempengaruhi keparahan korban kecelakaan lalu lintas di Kota Surabaya dengan pendekatan bagging regresi logistik ordinal. JURNAL SAINS DAN SENI ITS. 2012;1(1).

7. Budiyanto A, Widiatmaka W, Sudiono S, Mun'im TWA, Sidhi, Hertian S. Visum et repertum. Ilmu Kedokteran Forensik Indonesia. Jakarta: FKUI, 1997; h.5-7.

8. Henky, safitry O. Identifikasi Korban Bencana Massal Praktik DVI Antara Teori dan Kenyataan. Indonesian Journal of Legal and Forensic Sciences. 2012;2(1): 5-7.

9. Penggunaan babi dalam dunia kedokteran manusia. [cited 2013 sep 27]. Available from; http//www.repository.ipb.ac.id.

10. Whal LM, Whal SM. Inflammation. in: Cohen IK, Diegelmann RF, Lindbland WJ. (eds). Wound healing biochemical \& clinical aspects. Philadelphia: W.B. Saunders Company, 1992; p.40-62.

11. Sjamsuhidrajat R. De jong. Luka dan penyembuhan luka. Buku Ajar Ilmu Bedah (Edisi ke-3). Jakarta: EGC; h.95-120.

12. Idries AM. Pedoman ilmu kedokteran forensik. Jakarta: Binarupa Aksara, 1997; h.56-57,106.

13. Dekomposisi [hompage on the Internet]. [cited 2014 feb 10 ]. Available from: http://www.scribd.com/doc/97670462/Deko mposisi. 